\section{*Cevdet KAPLAN}

Orcid No: 0000-0001-7331-3508

\section{**M. Cemal ÇİFTÇí}

Orcid No: 0000-0003-2386-6969

*Siirt Üniversitesi, Ziraat Fakültesi,

Bitki Koruma Bölümü (Sorumlu yazar)

cevdetkaplan@siirt.edu.tr

**Siirt Üniversitesi, Ziraat Fakültesi, Bitki Koruma Bölümü

\section{DOI}

https://doi.org/10.46291/ISPECJASv ol4iss2pp51-65

Geliş Tarihi: $\quad$ 08/03/2020

Kabul Tarihi: 22/04/2020

\section{Anahtar Kelimeler}

Antepfıstığı, Antepfıstığ pisillidi (Agonoscena pistaciae Burck. and Laut.), yayılışı, popülasyon dinamiği

\section{Keywords}

Pistachio, Pistachio psylla (Agonoscena pistaciae Burck. and Laut.), distribution, population dynamics
Siirt İlinde Antepfıstığı Psillidi [Agonoscena pistaciae Burck. and Laut.) (Hemiptera: Aphalaridae)]'nın Yayılışı ve Populasyon Dinamiğinin Belirlenmesi

\section{Özet}

$\mathrm{Bu}$ çalışma 2015-2017 yıllarında Siirt İlinde Antepfistığında zararlı Antepfistığı psillidi [Agonoscena pistaciae Burck. and Laut.) (Hemiptera: Aphalaridae)]'nın yayılışı ve populasyon seyrini belirlemek amacıyla yürütülmüştür. Yayılış alanını belirlemek için Siirt İlinin Merkez, Aydınlar, Eruh, Kurtalan, Pervari, ve Şirvan ilçelerinde 24 köyde toplam 66 fistık bahçesinde gözlem ve inceleme yapılmıştır. Zararlının popülasyon seyrini belirlemek için ise 2016-2017 yıllarında Siirt Merkez ilçede 4 bahçede çalışmalar yürütülmüştür. Yayılış alanını belirlemek için darbe yöntemi ve göz ile inceleme yöntemi, mimf ve yumurta yoğunluğunu belirlemek için ise göz ile inceleme yöntemi kullanılmıştır. Örneklemeler 1-2 haftalık aralıklarla yapılmıştır. Çalışma sonucunda A pistaciae tüm ilçelerde yayılış gösterdiği ve kontrol edilen tüm bahçelerin bulaşık olduğu belirlenmiştir. Kışlanmış erginler nisan ayının ortasında, ilk yumurtalar nisan ayının son haftasında ve birinci dönem nimflere ise nisan sonu mayıs başında belirlenmiştir. Kış geçirecek ergin formları eylül ayı ortasından itibaren görülmüştür. A pistaciae'nın ergin, nimf ve yumurta yoğunluğunun mayıs sonu ve haziran başında biraz arttığı, ancak ağustos sonlarından kasım ortalarına kadar ergin, nimf ve yumurta yoğunluğunun yüksek olduğu tespit edilmiştir. Birçok bahçede ekonomik zarar eşiğini aştığ1 görülmüştür. Mayıs sonu- haziran başı ve temmuz sonu-ağustos ortasından sonra yapılacak kontrollerde eğer bileşik yaprak başına 20-30 nimf tespit edilirse bir yada iki kimyasal uygulama yeterli olacaktır.

Determination of The Distribution and Population Dynamics of Pistachio Psylla [Agonoscena pistaciae Burck. and Laut. (Hemiptera: Aphalaridae)].' in Siirt, Turkey

\begin{abstract}
This study was carried out in 2015-2017 with the aim of determining the distribution and population dynamics of Pistachio psylla [Agonoscena pistaciae Burck. and Laut.) (Hemiptera: Aphalaridae)] in Siirt province. In order to determine the distribution area, observation and examination were conducted in 66 pistachio orchards in 24 villages in Central, Aydınlar, Eruh, Kurtalan, Pervari, and Şirvan districts of Siirt. In order to determine the population dynamics of the pest, observation and examination were conducted in 4 pistachio orchards in Central district of Siirt. Beating and visual inspection method were used to determine the distribution area and visual inspection method was used to determine the density of nimf and egg stage of A. pistaciae. The sampling was done at 1-2 week intervals. As a result of the study, A. pistaciae was found to be distributed in all districts and all of the controlled orchards were infected. Wintered adults are determined in the middle of April the first eggs in the last week of April and the first nymph in late April-early May. The adults pass through winter were seen in middle of September. It was found that the population density of the nymph and egg of $A$. pistaciae increased slightly in late May and early June but its nymph, egg and adult population density was high from late August to mind November. That time it exceeded the economic loss threshold in many orchards. In the checks to be made in late May-early June and last july mid -August, one or two chemical applications will be sufficient if 20-30 nymphs are detected per compound leaf.
\end{abstract}




\section{GíRIŞ}

Antepfistığının (Pistachio vera, L) anavatanı Küçük-Asya, Kafkasya İran ve Türkmenistan' in yüksek kısımlarını içine alan Yakın-Doğu bölgesidir. Dünyada Antepfıstığının başlıca üretici ülkeleri; İran, ABD, Türkiye ve Suriye'dir. Ancak son yıllarda Çin'de antepfistığı dikim alanları giderek artmıştır. Dünyadaki antepfıstığı üretiminin \% 90'ni bu ülkelerde yapılmaktadır (Anonymous, 2017). Çerezlik olarak ve baklava sanayinde aranan, iç ve diş pazarda önemli bir ekonomik getiriye sahip olan Antepfıstığı Türkiye ekonomisine önemli katma değer sağlayan tarımsal ürünlerin başında gelmektedir. Antepfıstığı değerli bir meyve olması nedeniyle "Altın Ağacı", "Kralların Meyvesi", "Yeşil Altın" gibi adlarla da anılmaktadır. Antepfistığı özel iklim istekleri nedeniyle seçici bir bitki olup her yerde yetişmemektedir. $\mathrm{Bu}$ durum hem dünyada yetiştirici ülkeleri kısıtlarken hem de Türkiye'de de ancak belirli yörelerde yetişebilmektedir. Türkiye'de 55 ilde antepfıstığı yetişmektedir. Başlıca üretici iller Şanlıurfa, Gaziantep, Siirt, Adıyaman, Kahramanmaraş ve Mardin illeridir. Siirt ili Türkiye'de üretim ve dikim alanı itibariyle 3. sirada yer almaktadır. Siirt ilinde son yıllarda antepfıstığı dikim alanları giderek artmaktadır. Antepfistığı, periyodisite gösteren bir meyve türüdür. Üretim miktarı yıllara göre değişimler göstermektedir. TÜIKK 2018 y1lı verilerine göre; Türkiye'de toplam Antepfistığı ağaç varlığ 70.087 bin adet, Antepfistığı üretimin ise 240.000 tondur (Anonymous 2018a). Siirt Tarım Orman İl Müdürlüğü'nün 20018 yılı verilerine göre Siirt ilindeki Antepfıstığı ağaç varlığ 8 milyon adet olup bunun 5,5 milyonu verim çağındaki ağaçlar oluşturmaktadır. Antepfıstığı üretimin ise 15 bin ton civarındadir (Anonymous 2018b). Siirt ilinin fistık üretiminin 15-20 bin ton civarında olduğu ve Türkiye üretiminin \%12-15'ni karşılamaktadır. Siirt ilinde Siirt fıstık çeşidi yetiştirilmektedir. Siirt fistık çeşidinin iri, çıtlatma aralığının büyük, kabuğunun beyaz olması gerek iç piyasada gerekse diş piyasada çerezlik olarak iyi bir alıcı kitlesine sahiptir. Siirt ilinin tüm ilçelerinde Antepfıstığ yetiştiriciliği yapılmasına rağmen daha çok Merkez, Eruh, Kurtalan ve Pervari ilçelerinde yetiştirilmektedir. Antepfistığ Siirt ilinde tarımsal üretim ile iştigal eden üreticiler için önemli bir gelir kaynağı oluşturmaktadır. Özellikle son beş yılda dikim alanları giderek artmıştır. Dikim alanlarının artması sonucunda yetiştirme teknikleri yanında verim ve kaliteyi 
olumsuz etkileyen bitki koruma sorunların artmıştır. Antepfıstığ 1 yetiştiriciliğinde en önemli sorunları ağaç ve dal kurumaları, çiçek ve meyve dökümleridir. Bu sorunlar çoğunlukla iklim koşulların seyrine, fizyolojik etkenlere, bahçe içerisinde yetersiz erkek ağaç sayısı, hastalık etmenleri ve zararlı böcek türlerinden kaynaklanmaktadır. Zararlı böcekler Antepfıstığında çiçek ve küçük meyve dökümüne neden olmaları yanı sıra, meyve tutumundan sonra da oluşturdukları zararlar nedeniyle verimi önemli ölçüde düşürmekte, ağacı zayıflatarak bir sonraki yılın ürün miktarını olumsuz yönde etkilemektedir. İran'da Antepfıstıklarında zararlı böcek türlerinin \% 50 oranında ürün kayıplarına neden olduğunu belirtilmektedir (Davatchi, 1958). Agonoscena pistaciae Türkiye'de Antepfıstığı bahçelerinde yaygın olan ve en önemli zararlı böcek türüdür. $A$. pistaciae'nın ergin ve nimfleri Antepfıstığı ağaçlarının yapraklarında emgi yapmakta, emgi sonucunda fumajin oluşturarak hastalık etmenlerinin gelişmesi için uygun ortam oluşturmaktadır. Yoğun popülasyonlar da, ağaçlarda erken yaprak, çiçek ve meyve dökümüne neden olmakta, ayrıca meyve oluşturacak olan karagözler yeterince beslenmemekte ve dökülmektedir. Bunun sonucunda bir sonraki yıl oluşacak ürün miktarının azalmasına neden olmaktadır. (Anonymous, 2011). Son yillarda Antepfıstığı bahçelerinde yapılan bilinçsiz kimyasal ilaç uygulamaları sonucunda Antepfıstığı alanlarında var olan doğal denge giderek bozulmuş ve kimyasal ilaç uygulamaları yapılan bahçelerde $A$. pistaciae'nın yoğunluğu giderek artmıştır. Türkiye'de Antepfıstığı ağaçlarında zararlı A. pistaciae'nın tespiti, populsayon gelişimi ve mücadelesi ile ilgili yapılan bazı çalışmalar bulunmaktadır. Bu çalışmaların (Tokmakoğlu, 1973; Günaydın, 1978; Çelik 1981; Mart ve ark., 1995; Bolu ve Kornoşor, 1995 ; Kaplan ve Çınar, 2000; Şimşek ve Bolu, 2017; Kaplan ve Çiftçi, 2019) çoğu Güneydoğu Anadolu bölgesinde yapılmıştır. Ancak Siirt ilinde geniş Antepfıstığı alanları olmasına rağmen A. pistaciae üzerinde detaylı bir çalışma olmadığında bu çalışma ele alınmıştır. Bir zararlı ile iyi bir mücadele yapabilmek için öncellikle zararlının beslenme davranışı biyolojisi ve ekolojisinin bilinmesine ihtiyaç duyulmaktadır.

$\mathrm{Bu}$ çalışma Siirt İlinde “Antepfıstığ (Pistacia vera L.) Hastalık ve Zararlıların Tespiti ve Önemli Türlerin Mücadeleye Esas Kritik Dönemlerinin Belirlenmesi” 
adlı proje kapsamında yapılan çalışma sonucunda en yaygın ve yoğun zararlı olarak tespit edilen Antepfistığ pisillidi (Agonoscena pistaciae Burck. and Laut.)'nın yayılış alanı, populasyon dinamiği ve mücadeleye esas kritik dönemlerin tespiti konusunda elde edilen bilgiler bu makalede derlenmiştir.

\section{MATERYAL VE YÖNTEM}

Çalışmanın ana materyalini Siirt fıstığı ağaçları ve Antepfistığı psillidi (Agonoscena pistaciae)'nin değişik biyolojik dönemleri (ergin, yumurta ve nimf) oluşturmuştur. Böcek toplama malzemeleri ve laboratuvar malzemeleri ise diğer yardımcı materyalleri oluşturmuştur.

Antepfistığı psillidi (Agonoscena pistaciae

Burck. and Laut.)'nın yayılış alanının tespiti

Seçilen her bahçede GRIGOROV (1974), yöntemi uygulanmıştır. Buna göre;

20 ağacı olan bahçelerin tamamı,

21-70 arasında ağaç olan bahçelerde 20-30 ağaç

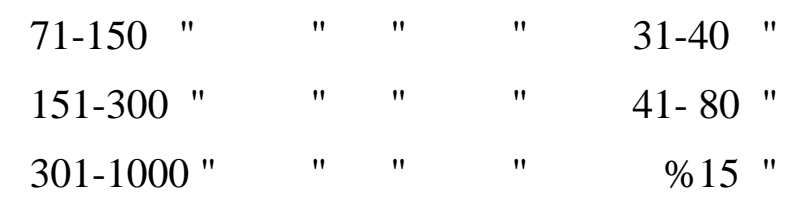

1000 'den fazla ağaç olan bahçelerde \%5 ağaç kontrol edilmiştir.

Örneklemeler her bahçeyi temsil edecek nitelikte yukarıda belirtilen sayıda ağaçta yapılmıştır. Ergin bireylerin örneklenmesinde STEINER (1962) metodu olarak bilinen silkme metodu kullanılmıştır.

Nimf ve yumurta dönemlerinin tespiti için ise göz ile kontrol yöntemi kullanılmıştır (Anonymous, 2011) 


\section{Antepfıstığı bahçelerinde Antepfıstığı}

pisillidi (Agonoscena pistaciae Burck. and

\section{Laut.)) populasyon dinamiğinin tespiti}

Agonoscena pistaciae'nın doğada

Siirt fistık çeşidinde değişik biyolojik

dönemlerin (nimf, yumurta, parazitli yumurta) popülasyon takibi Siirt Merkez ilçeye bağlı farklı yörelerde bulunan ve özellikleri Çizelge 1'de belirtilen 4 bahçede 2016-2017 y1llarında yapılmıştır.

Çizelge 1. 2016-2017 yıllarında Siirt İlinde (Merkez ilçede) (Agonoscena pistaciae Burck. and Laut.)'nın popülasyon takibi çalışmaların yürütüldüğü bahçelerin özellikleri

\begin{tabular}{lllll}
\hline \multicolumn{1}{l}{ Yer } & Çeşit & \multicolumn{2}{c}{ Ă̆aç } \\
\hline & & & Yaş & Sayısı \\
\cline { 2 - 5 } & Merkez bahçe1 & Siirt & $30-35$ & 440 \\
\cline { 2 - 5 } $\begin{array}{l}\text { Siirt } \\
\text { Merkez }\end{array}$ & Merkez bahçe2 & Siirt & $25-30$ & 320 \\
\cline { 2 - 5 } & Merkez bahçe3 & Siirt & $25-30$ & 360 \\
\cline { 2 - 5 } & Kezer & Siirt & $18-20$ & 200 \\
\hline
\end{tabular}

Ergin yoğunluğunun tespiti darbe yöntemi ile ve yapraktaki sayısını belirlemesi pek sağlıklı olmadığından zararlının mücadelesinde esas alınan nimf ve yumurta yoğunluğunun popülasyon takibi yapılmıştır. Ergin dönemdeki bireylerin doğaya çıkışı ve kışlayacak formların tespiti ise darbe yöntemi ile belirlenmeye çalışılmıştır. Zararlının yumurta ve nimf dönemlerinin yoğunluğunu ile parazitli nimf sayısını belirlemek için; her bahçede 25 ağacın değişiik yön ve yüksekliklerinden 4'er yaprak olmak üzere, her bahçede toplam 100 yaprak alınmıştır. Alınan yaprak örnekleri önce kese kâğıdına sonra polietilen bir torbaya yerleştirilerek buz kutusu içerisinde laboratuvara getirilmiştir. Laboratuvarda yaprak örneklerinin alt ve üst yüzeyleri stereomikroskop altında incelenerek $A$. pistaciae'nin yumurta ve nimf dönemleri ile parazitli nimf sayımı yapılmıştır (Anonymous 2011).

\section{BULGULAR}

Antepfıstığı psillidi (Agonoscena pistaciae Burck. and Laut.)'nın yayılış alanının

\section{tespiti}

Siirt İli fistık üretim alanlarında 2015-2017 yılları arasında yapılan sörvey çalışmalarında; A. pistaciae'nın Siirt merkez, Aydınlar, Kurtalan, Eruh, Şirvan ve Pervari ilçelerinde ilçe merkezlerinde ve köylerinde gözlem ve inceleme yapılan 66 
bahçede tespit edilmiştir. A. pistaciae'nın Siirt ilinde Siirt fistığı çeşidinin yetiştirildiği tüm bahçelerde yaygınlık gösterdiği ve en önemli zararlılar arasında yer aldığ 1 belirlenmiştir.

Antepfıstığı pisillidi (Agonoscena pistaciae Burck. and Laut.)'nın populasyon

\section{dinamiğinin tespiti}

Agonoscena pistaciae kışlık formları 2016 yılında ilk uçuşları 16 Nisanda, ilk yumurtaları ise 25 Nisan tarihinde tespit edilmiştir. 29 Nisan tarihinde yumurta populasyonundaki artışların yanı sıra birinci dönem nimfler de tespit edilmiştir. Y1l içerinde populasyon takibi yapılan bahçelerden Siirt Merkez 1 nolu bahçede $A$. pistaciae" nin tüm biyolojik dönemlerinin Mayıs ayından ekim ortalarına kadar bahçede görülmüştür. En yüksek nimf yoğunluğuna 51,2 adet nimf/bileşik yaprak) 24 A ğustos tarihinde saptanmıştır. Zararlının bu bahçede yıl boyunca Ekonomik Zarar Eşiğini (EZE) aştığı görülmektedir (Şekil 1-2).

Siirt Merkez 2 nolu bahçede 2016 y1lında A. pistaciae'nın yoğunluğunun yüksek olduğu ve mayıs ayından hasat sonrası ekim ayı ortasına kadar zararlının tüm biyolojik dönemleri (yumurta, nimf ve ergin) yapraklarda belirlendiği, en yüksek nimf yoğunluğuna $(54,7$ adet nimf/bileşik yaprak) 25 Temmuz tarihinde ulaştı̆̆ görülmüştür. $\mathrm{Bu}$ bahçede A. pistaciae'nin temmuz ve ağustos aylarında EZE ( 20-30 nmf/ bileşik yaprak)'ni aştığı görülmüştür.

Siirt Merkez 3 nolu bahçede diğer iki bahçedeki gibi bir benzerlik gösterdiği en yüksek nimf yoğunluğunu (40, 8 nimf/bileşik yaprak) 30 Eylül tarihinde oluşturduğu, zararlının ağustos, eylül ve ekim ayalarında EZE aştığı görülmüştür.

Siirt Kezer'deki bahçede A. pistaciae yoğunluğunun çok düşük seyrettiği ve y1l boyunca EZE'ni aşmadığı görülmektedir.

Y1l içerisinde en yüksek nimf yoğunluğu 2,7 nimf/bileşik yaprak ile 13 Temmuz 2016 tarihinde belirlenmiştir (Şekil 2).

Populasyon takibi yapılan 4 bahçedeki zararlının durumu birlikte değerlendirildiğinde; Siirt ilinde fistık alanlarında önemli zararlı türlerden olan $A$. pistaciae 'nin kışlık formlarının (kışlayan bireyler) ilk uçuşları 16 Nisan, ilk yumurtaları 25 Nisan tarihinde tespit edilmiştir. 29 Nisan 2016 tarihinde yumurta populasyonundaki artışların yanı sıra 1 . dönem nimfler de tespit edilmiştir. Y1l içerisinde zararlının Siirt Merkez'deki 3 bahçede Ekonomik Zarar Eşiğini (EZE) (20-30 nimf/bileşik yaprak) aştığı ancak Kezer'deki bahçede yoğunluğun oldukça düşük olduğu ve yıl boyunca EZE'nin 
altında kaldığ1 görülmektedir. Yoğunluğun temmuz ayından itibaren artığı, ağustos ve eylül arasında en yüksek noktaya ulaşmıştır.

A. pistaciae kışlık ergin formlarına Eylül ortasından itibaren rastlanmıştır. Ekim ortasına kadar yumurtaları görülmüştür. (Şekil 1, 2).

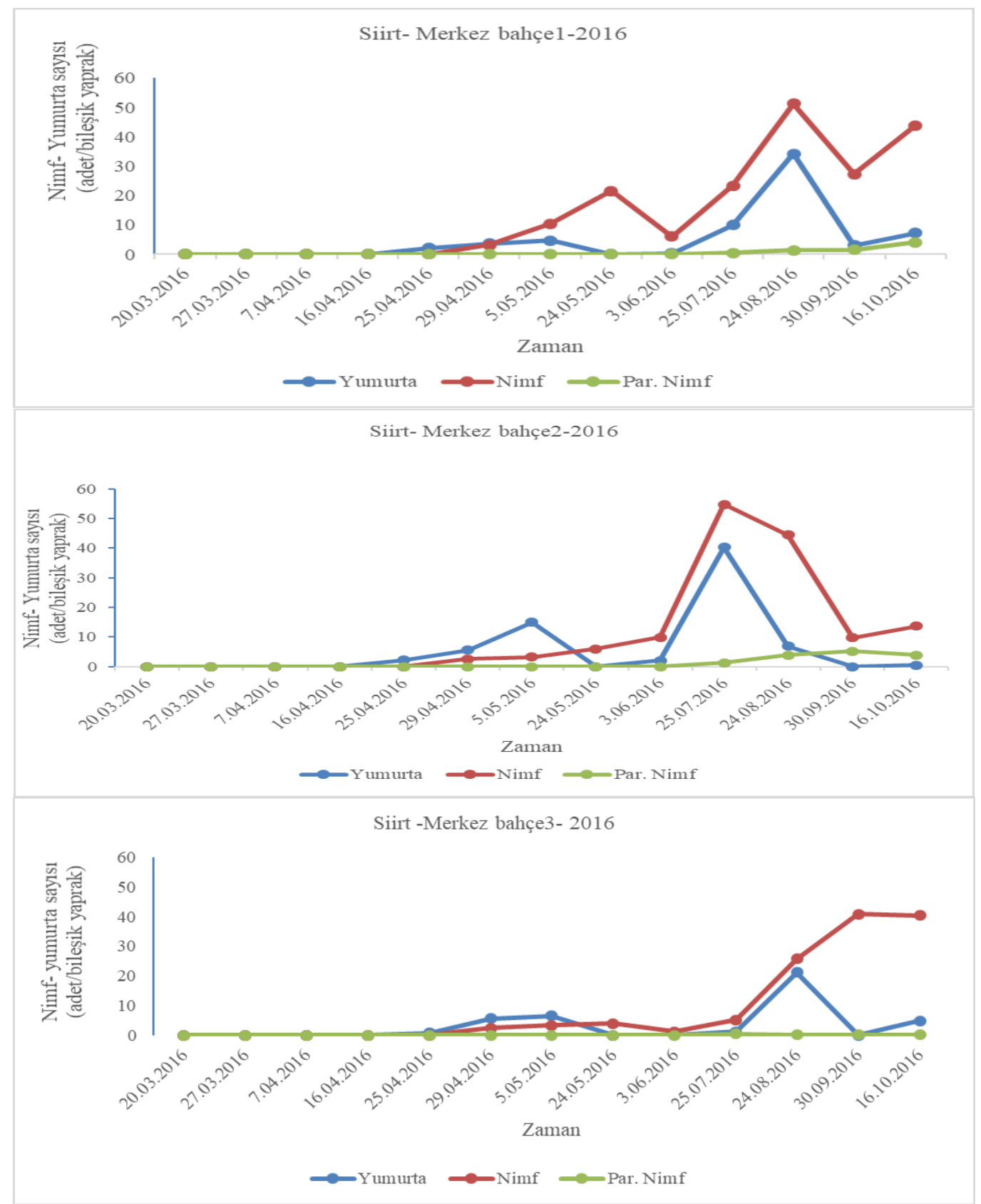

Şekil 1. Antepfıstığı pisillidi (Agonoscena pistaciae Burck. and Laut.'nın 2016 yılında Siirt Merkez ilçedeki 3 bahçedeki populasyon değişimi. 


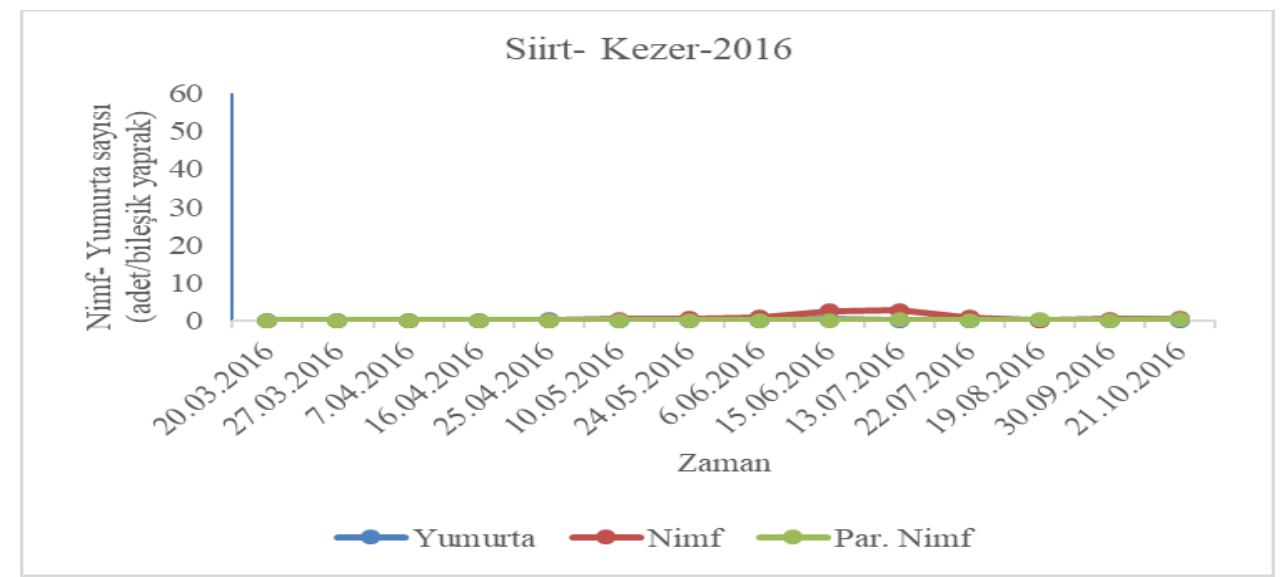

Şekil 2. Antepfıstığı pisillidi (Agonoscena pistaciae Burck. and Laut.)'nın 2016 yılında Siirt (Kezer) ilindeki populasyon değişimi.

Çalışmaların yürütüldüğü 2017 yılındaki gözlemlerde; populasyon takibi yapılan Siirt Merkez 1 nolu bahçede 2017 yılında zararlının yumurta ve nimflerine 3 Mayıs tarihinde rastlanmıştır. Bahçede yıl boyunca zararlının değişik biyolojik dönemleri görülmüştür. 15 Kasım tarihine kadar yapraklarda nimfler belirlenmiştir. $\mathrm{Bu}$ bahçede ağustos ayından itibaren yumurta nimf ve ergin sayısında artış gözlenmiştir. En yüksek nimf yoğunluğu (107,6 nimf/bileşik yaprak) 21 Eylül tarihinde tespit edilmiştir. Zararlı eylül ve ekim aylarında EZE'ni aşmıştır (Şekil 3). Siirt Merkez 2 nolu bahçede 2017 yılında $A$. pistaciae'nın mayıs ve kasım ayları arasında değişik biyolojik dönemleri görülmüştür. Mayıs ayının ilk haftasından itibaren zararlının yumurtaları belirlenmiştir. 8 Haziran tarihinde nimf yoğunluğunda artış görülmüştür. Zararlının ağustos ayı içerisinde yumurta ve nimf sayısında artışın başladığı ve kasım ortasına kadar nimfleri görülmüştür. En yüksek yumurta yoğunluğu $\quad(26,8 \quad$ adet yumurta/bileşik yaprak) 23 Ağustos tarihinde, en yüksek nimf yoğunluğu (107,06 nimf/bileşik yaprak) ise 21 Eylülde görülmüştür. $\mathrm{Bu}$ bahçede zararlının eylül ayı içerisinde EZE'ni aştığ1 görülmüştür (Şekil 3). Agonoscena pistaciae'nin 2017 yılında Siirt Merkez 3 nolu bahçedeki yoğunluğu incelendiğinde; zararlının yumurta ve nimflerinin mayıs ayının başından itibaren görülmeye başladığı ve kasım ayı ortasına kadar bahçede nimflerine rastlanılmıştır. Haziran ayı ortasında nimf yoğunluğunda artış (9,06 nimf/bileşik yaprak) olduğu bu dönemde ancak EZE'ni aşmadığ1 görülmüştür. Ancak ağustos ayı ortasından itibaren ergin ve yumurta sayında meydana gelen artış sonucu eylül 
ve ekim aylarında nimf yoğunluğunun artarak devam ettiği ve EZE'ni aştığı belirlenmiştir. Y1l içerisinde en yüksek nimf yoğunluğunu (71,6 nimf/bileşik yaprak) 21 Eylül tarihinde oluşturduğu görülmüştür (Şekil 3). Kış1 geçirecek ergin bireylere 21 Eylül tarihinde rastlanılmıştır.
Kezer bahçesinde ise 2017 yılında $A$. pistaciae erginleri 26 Nisan tarihinde görülmüştür. Yumurtalarına ise 3 Mayıs tarihinde rastlanılmıştır. Zararlı bu bahçede çok düşük yoğunlukta seyretmiştir. Zararlının nimflerine 23 Ekim tarihine kadar rastlanılmıştır.

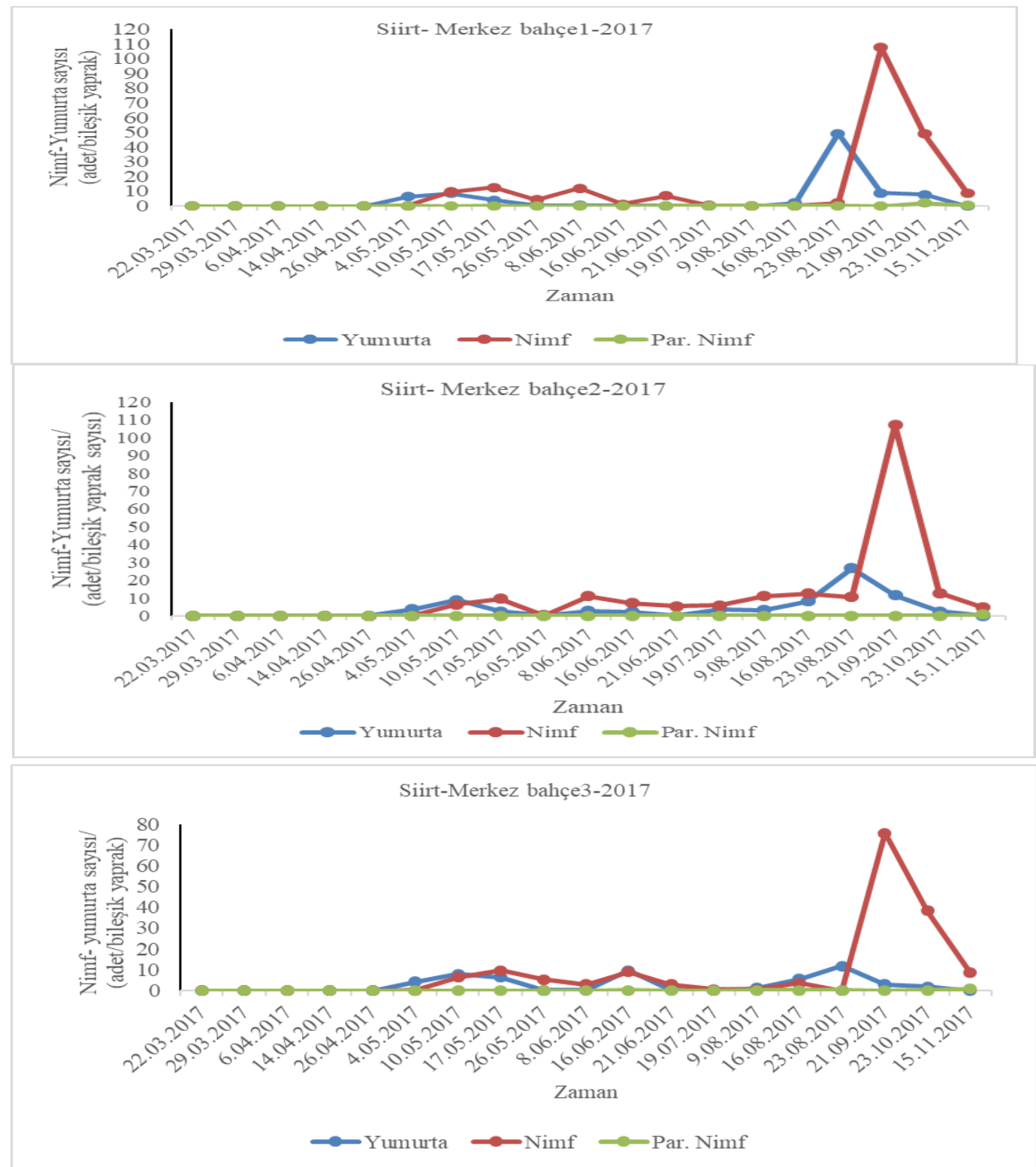

Şekil 3. Antepfistığı pisillidi (Agonoscena pistaciae Burck. and Laut.'nın 2017 yılında Siirt Merkez ilçedeki 3 bahçedeki populasyon değişimi. 


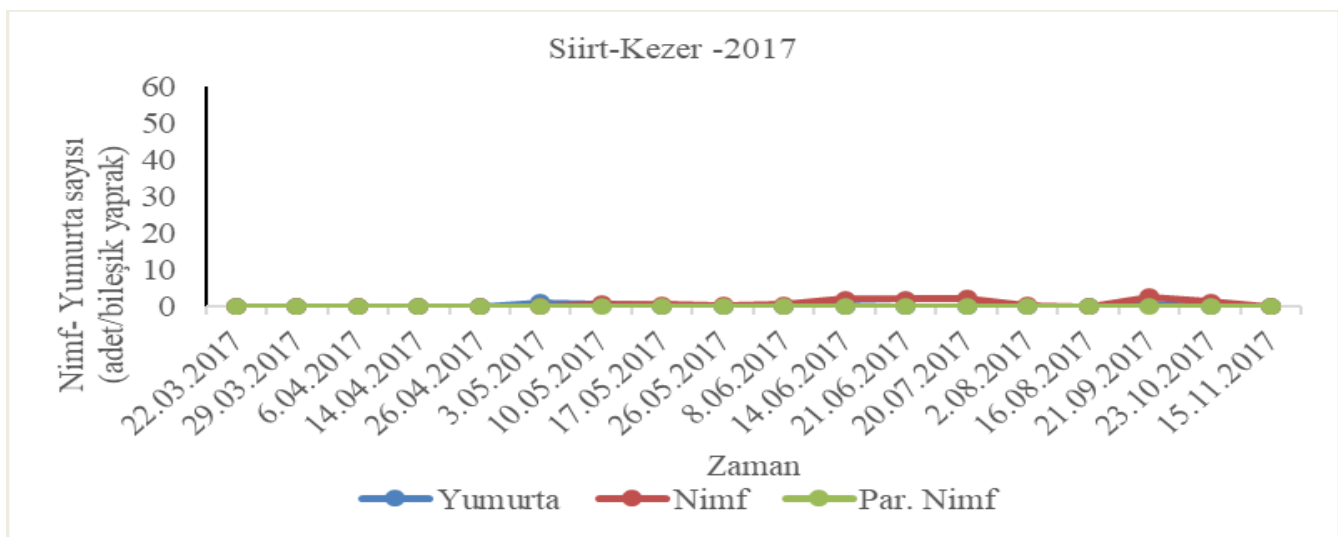

Şekil 4. Antepfıstığı pisillidi (Agonoscena pistaciae Burck. and Laut.'nın 2017 yılında Siirt- Kezer'deki bahçedeki populasyon değişimi.

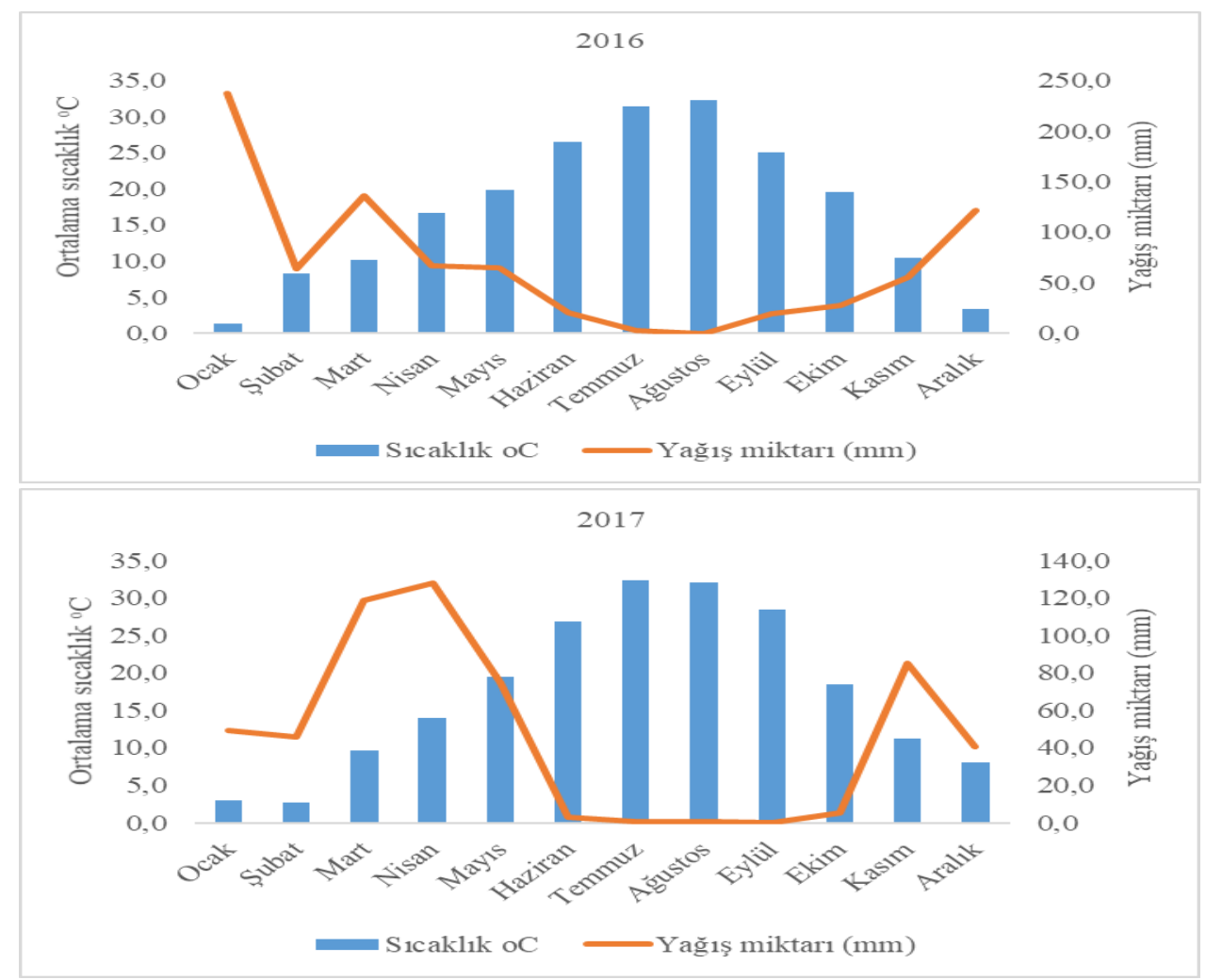

Şekil. 5. Siirt İlinin 2016-2017 yılları iklim verileri.

Kezer'deki bahçede A. pistaciae'nın 2017 yılında EZE'ni aşmadığ 1 ve yıl içerisinde en yüksek nimf yoğunu 21 Eylül tarihinde ancak 2,6 nimf/bileşik yaprak düzeyinde olmuştur (Şekil 3). Siirt ilinde
2016-2017 yıllarında iklim verileri (yağış ve sıcaklık) birbirine yakın olmuştur (Şekil 5). Ancak 2017 yılında mart ve nisan ayında yağışların daha fazla olduğu görülmektedir. İklim verilerinden sıcaklık ve yağışın 
zararlı böceklerin doğaya çıkışlarında ve üremeleri üzerinde oldukça etkilidir. 2017 yılında mart ve nisan ayının daha fazla yağışlı olması ve sıcaklığın çak az da olsa düşük olması nedeniyle örnekleme bahçelerinde 2016 yılına göre daha geç $A$ pistaciae'nin kışlamış ergin, nimf ve yumurtalarına rastlanılmıştır ve zararlı daha geç yoğunluk oluşturduğu görülmüştür (Şekil 1,3).

\section{TARTIŞMA VE SONUÇ}

Siirt İlinde fistık bahçelerin 2015-2017 y1lları arasında yapılan sörvey çalışmalarında; A. pistaciae'nın Siirt merkez, Aydınlar, Kurtalan, Eruh, Şirvan ve Pervari ilçelerinde örnekleme yapılan 66 bahçede tespit edilmiştir. A. pistaciae'nın Siirt ilinde Siirt fistığı çeşidinin yetiştirildiği tüm bahçelerde yaygınlık gösterdiği ve en önemli zararlılar arasında yer aldığı belirlenmiştir.

Daha önce yapılan çalışmalarda $A$. pistaciae'nın İzmir, Manisa, Gaziantep, Şanlıurfa, Mardin, Diyarbakır ve Siirt illerinde tespit edilmiştir (Tokmakoğlu, 1973; Günaydın, 1978; Çelik, 1981; Önuçar, 1983; Bolu ve Kornoşor, 1995; Bolu ve ark., 1999; Kaplan ve Çınar, 2000).

A. pistaciae'nın İran'da fistık alanlarında yaygın olduğu ve en önemli zararlılar arasında yer aldığı belirtilmektedir
(Najafpour ve ark., 2010; Mehrnejad, 2001). Mourikis ve ark. (1998), Yunanistan'da fistık ağaçlarında Psyllid Agonoscena sp.'in erken yaprak dökümüne neden olduğunu belirtmektedirler.

Çalışma sonucunda Siirt ilinde fistık alanlarında önemli zararlı türlerden olan $A$. pistaciae'nın kışlık formlarının ilk uçuşları yıllara göre göre değişmekle beraber genellikle nisan ayının ikinci haftasından sonra başladığı ve ilk yumurtaları ise nisan ayının son haftasında tespit edilmiştir. Nisan sonlarında yumurta sayısında artış görülmüş nisan sonu mayıs başından itibaren 1. dönem nimfler de tespit edilmiştir. Yıllara göre değişmekle beraber zararlının nimflerine nisan sonundan kasım ayı ortalarına kadar bahçelerde görülmüştür.

Gaziantep ve ilçelerinde A. pistaciae'nın kışlamış erginleri nisan ayının başlarında tespit etmiştir (Tokmakoğlu, 1973). Günaydın (1978), Güneydoğu Anadolu Bölgesi Antepfıstığı bahçelerinde ilk kışlanmış ergin A. pisatciae bireylerine nisan ayı başlarında rastlamıştır. Gaziantep'te Nizip ve Firat vadisi alt bölgelerinde Mart ayı ortasından itibaren Gaziantep Merkez İlçed, Arıl, Battal vadisi, Oğuzeli, Yavuzeli ve Araban alt bölgesinde NNisan ayı başında , Gaziantep'in yüksek 
ve dağlık yerdeki Antepfıstığ yetiştirilen yerlerde ise nisan ayının ilk haftasından ve ortasında ilk kışlık erinlerin doğada tespit edildiği bildirilmektedir (Çelik, 1981). Bolu ve Kornoşor (1995), Şanlıurfa ilinde $A$. pistaciae'nın kışlık erginlerinin 8 nisan tarihinde görüldügünü belirtmektedirler. Şanlıurfa ilinde A. pistaciae erginleri nisan ayı içinde kışlamış ergine ait yumurtalara ve nimflere mayıs ayının ikinci haftasında itibaren rastlanılmıştır (Kaplan ve Çınar, 2000).

Çalışma sonucunda A. pistaciae'nın yoğunluğu fistık üretiminin yoğun yapıldığı alanlarda yüksek, lokal yetiştiriciliğin yapıldığı bölgelerde daha düşük olduğu gözlemlenmiştir. A. pistaciae'nın nimf yoğunluğunun mayıs sonu ve haziran başında hafif yükseldiği ancak bu dönemde EZE'ne ulaşmadığı görülmüştür. $A$. pistaciae'nın yoğunluğunda temmuz ayı ortalarında itibaren arttığı ve ağustos eylül aylarında en yüksek noktaya ulaştığı belirlenmiştir. Zararlının temmuz, ağustos ve eylül aylarında bazı bahçelerde ekonomik zarar eşiğini aştığı görülmüştür. Kasım ayı ortalarına kadar yoğunluğunun yüksek olduğu saptanmıştır. Eylül ortalarında itibaren A. pistaciae'nın erginlerinde rengin koyulaşmaya başladığı ve kışı geçirecek erginler görülmüştür.
Ancak Bolu ve Kornoşor (1995) yaptıkları çalışmada A. pistaciae populasyonun mevsim başında artarak temmuz ayının son haftasına kadar devam ettiği temmuz sonu, ağustos ve 15 eylül'e kadar tüm mevsimde en düşük populasyon belirlenmiştir. Yazlık formlar 20 Mayıs kışı geçirecek formlar ise çalışmaların yürütüldüğü bahçelerde 30 eylül tarihinde tespit etmiştir.

A.pistaciae'nın populasyonunda haziran ayı ortalarında artış olduğu, temmuz ve ağustos aylarında azaldığı eylül ayının ikinci, haftasından itibaren populasyonun da artarak devam ettiği, zararlının ekonomik zarar eşiğini haziran ayının ortasında, eylül ve ekim aylarında aştığını saptanmıştır (Kaplan ve Çınar, 2000). Najafpour ve ark. (2010), İran'da Antepfıstığı alanlarında ana zararlı olan Agonoscena pistaciae Burckhardt \& Lauterer 'nın yoğunluğu ve populasyon dinamiğini tarla koşullarında Badami-riz Zarand ve Momtaz yerli ve lokal çeşitlerinde gözlemiştir. Psyllid nimf yoğunluğunun nisan ayından ekim ayına kadarki örnekleme zamanının tümünde Momtaz çeşidinden Badami-riz Zarand'a göre daha yüksek olduğu, Psyllid nimf yoğunluğunun temmuz sonunda yükseldiği ancak ağustos ve daha sonra dönemde hızlı bir şekilde artığını belirtmektedirler. 
Sonuç olarak A. pistaciae Siirt ilinde Siirt fıstığ 1 yetiştirilen tüm bahçelerde görülmektedir. Ancak fıstık yetiştiriciliğin yaygın yapıldığı bölgelerde ve kimyasal kullanımın çok olduğu bahçelerde doğal dengenin bozulması nedeniyle bu tür bahçelerde $A$. pistaciae yoğunluğunun ve zararın daha fazla olduğu görülmüştür. Siirt ilinde kışlanmış erginleri yıllara göre değişmekle beraber genellikle fistıkların yapraklanmaya başladığı nisan ayı ortalarından itibaren görülmektedirler. Kışlamış ergin yumurta ve nimfleri nisan sonu mayıs ayı başlarında rastlanılmaktadır. Yumurta, nimf ve ergin yoğunluğu mayıs ayı son haftasında itibaren artmakta ve bazı bahçelerde ilaçlamayı gerektirecek yoğunluğa erişmektedir. Mayıs ve haziran aylarında bahçelerde pisillid ile beslenen çok sayıda Coccinellidae türleri bahçelerde görülmektedir. Bu dönemde ilaçlamalara karar verirken mutlaka bahçedeki faydalı böceklerin yoğunluğu dikkate alınmalıdır. Yapılan çalışmada az da olsa özellikle haziran temmuz ve ağustos aylarında parazitlenmiş nimflere rastlanmıştır. Ancak oran oldukça düşük düzeyde seyretmiştir. Siirt ili için A. pistaciae ile yapılacak kimyasal mücadelenin mayıs sonu haziran ayı başında bileşik yapraklarda yapılacak kontrollerde eğer bileşik yaprak başına 20-
30 nimf görülmesi durumunda ilaçlama yapılmalıdır. İkinci bir ilaçlama temmuz sonu ağustos ortalarına doğru yapılacak gözlemlerde bileşik yapraktaki nimf sayısı EZE ( 20-30 nimf/bileşik yaprak) aşıyorsa ikinci bir uygulama yapılabilir.

\section{TEŞEKKÜR}

Bu çalışma Siirt Üniversitesi BAP birimi tarafindan desteklenen Proje kodu 2015SIÜZİR-12 olan "Siirt İlinde Antepfıstığ1 (Pistacia vera L.) Hastalık ve Zararlıların Tespiti ve Önemli Türlerin Mücadeleye Esas Kritik Dönemlerinin Belirlenmesi” isimli proje kapsamında yürütülmüştür. Proje çalışmalarına sağladığı maddi destekler için Siirt Üniversitesi BAP Koordinatörlüğüne teşekkür ediyorum.

\section{KAYNAKÇA}

Anonymous, 2011. Antepfistığı Entegre Mücadele Teknik Talimatı, Gıda Tarım ve Hayvancılık Bakanlığı, Tarımsal Araştırmalar ve Politikalar Genel Müdürlüğü, Bitki sağlığı Araştırmaları Daire Başkanlığı, Ankara.

Anonymous,2017.(http://www.fao.org/f aostat/en/\#data/QC) Erişim Tarihi: 20.05.2019).

Anonymous, 2018a. Tarımsal Yap1 (Üretim, Fiyat, Değer) T.C. Başbakanlık Devlet İstatistik Enstitüsü 
Yayınları.(http://www.tuik.gov.tr/PreTablo

?alt|_id=1001. Erişim tarihi: 10.04.2020)

Anonymous, 2018b. Türk Tarım Orman (http://www.turktarim.gov.tr/Haber/255/bir -basari-hikayesi-yesil-altin-siirt-fistigi,

Erişim tarihi: 10.05.2020)

Bolu, H., Kornoşor, S., 1995. Şanlıurfa İlinde farklı iki antepfıstığı çeşidinde Agonoscena pistaciae Burckhardt and Lauterer (Homoptera, Psyllidae)'nın populasyon değişimi. GAP Bölgesi Bitki Koruma Sorunları ve Çözüm Önerileri Simpozyumu, 27-29 Nisan 1995, Şanlıurfa, 165-176.

Çelik, Y. 1981. Gaziantep ve Çevresinde Antepfistıklarında Psylloidae'ya Bağlı Önemli Zararlı Türlerin Tanınmaları. Yayılışları. Konukçuları, Kısa Biyolojileri ve Doğal Düşmanları Üzerinde Araştırmalar. Arş. Es. Ser. No. 51. 108 s.

Davatchi, G.A., 1958. Sur Quelques insectes Nuisibles Au Pistachier En Ġran. Revue de Pathologie Vegatale et Entomologie Agricole de France. Tome XXXVII. No 1 Paris;166 s.

Günaydın, T., 1978. Güneydoğu Anadolu Bölgesinde Antepfistıklarında Zarar Yapan Böcek Türleri, Tanınmaları, Yayılışları ve Ekonomik Önemleri Üzerinde Araştırmalar. (Basılmamış
Uzmanlık Tezi. E.Ü. Zir. Fak. Bit. Kor. Böl.), Bornova, İzmir, s. 106.

Kaplan, C., Çınar M., 2000. Şanlıurfa İlinde Agonoscena pistaciae Burk and Laut (Hom: Psyllidae)'nin populasyon değişimi ve bazı doğal düşmanları (Hemiptera: Anthocoridae, Miridae ve Lygaeidae). Türkiye IV. Entomoloji Kongresi, 12-15 Eylül 2000, Kuşadası, 137-144.

Kaplan, C., Çiftçi, M.C., 2019. Siirt İlinde Antepfistığ 1 zararlılarının tespiti. International Engineering and Science Symposium. 20-22 June 2019, Siirt, p:15.

Lazarov, H., Grigorov, S., 1958, Entomologia. Zemizdat, Sofia 453 pp

Mart, C., Erkılıç, L., Uygun, N., Altin, M., 1995. Species and pest control methods used in pistachio orchards of Turkey. Acta Horticulturae 1995 No. 419 pp. 379-385.

Mehrnejad, M. R., 2001, The current status of pistachio pests in Iran. Cahiers Options Méditerranéennes 2001 Vol. 56 pp. 315-322.

Mourikis, P. A., Tsourgianni, A. Chitzanidis, A., 1998. Pistachio nut insect pests and means of control in Greece. Acta Horticulturae 1998 pp. 604-611.

Najafpour, F., Mehrnejad, M. R. Fallahzadeh, M., 2010. Population dynamics and density of the common pistachiopsylla, Agonoscena 
pistaciae (Hemiptera: Psyllidae) on two pistachio cultivars, Badami-riz Zarand and Momtaz. Plant Protection Journal 2010 Vol. 2 No. 3 pp. 209-221.

Önuçar A., 1983. İzmir ve çevresinde bitkilerde zararli psyllid (Homoptera:Psyllinea) türlerinin tanınmaları, konukçuları ve taksonomileri üzerinde araştırmalar. Tarım ve Orman Bakanlığı, Zirai Mücadele ve Zirai Karantina Genel Müdürlüğü, İzmir Bölge Zirai Mücadele Araştırma Enstitüsü Müdürlüğü, Araştırma Eserleri Serisi No:44, Ankara, $122 \mathrm{~s}$.
Steiner, H., 1962. Anleitung zum Integrierten Pflanzenschutz im Apfelan Bau (O.I.L.B.). Lanolesanstalt für Pflanzenschutz Stutgart. 7:207-214.

Şimşek, A., H. Bolu, 2017. Diyarbakır ili $\begin{array}{llll}\text { antepfistığı (Pistacia vera L.) } & \end{array}$ bahçelerindeki zararlı böcek faunasının belirlenmesi. Dicle Üniversitesi Fen Bilimleri Enstitüsü Dergisi, 6 (2): 43-58.

Tokmakoğlu, C. 1973. Antepfistığı (Pistaciae vera) zararlıs1 Agonoscena targionii Licht. böceğinin biyolojisi ve mücadele ile ilgili bazı tespitler. Bitki Koruma Bülten, 13 (2): 62-67. 